\title{
Disrupting to sustain: Teacher preparation through innovative teaching and learning practices
}

Daniel Morales Morales ${ }^{1}$, Carie Ruggiano ${ }^{1}$, Cee Carter ${ }^{1}$, Kimberly J. Pfeifer ${ }^{1}$, and Keisha L. Green ${ }^{1 *}$

${ }^{1}$ The University of Massachusetts Amherst

*Corresponding Author: klgreen@umass.edu

Received : 2019-NOV-02

Accepted : 2020-JUN-01

d

DOI: $10.46303 /$ jcve.03.01.1

How to cite this paper: Morales Morales, D., Ruggiano, C., Carter, C., Pfeifer, K. J., \& Green, K. L. (2020). Disrupting to sustain: Teacher preparation through innovative teaching and learning practices. Journal of Culture and Values in Education, 3(1), 1-20. https://doi.org/10.46303/jcve.03.01.1

\begin{abstract}
The main purpose of this paper is to respond to the call to re-envision higher education and to share experiences of hope that provide concrete examples about possibilities of enacting liberatory education in higher education. This article focuses on the work of one junior faculty member and four doctoral students who participate in a critical inquiry group and research collective called the Critical Education Research Collective. As social justice educators, in this shared space we engage in meaningful teaching and inquiry practices that involve teaching and research methodologies, education theory, dialogue, reflection and praxis. While research has highlighted the ways in which inquiry groups can be used as an intentional and systematic examination into teaching practice, this essay describes the structure, functioning, theoretical standpoints, and the process of becoming a doctoral student and professor-led critical inquiry group. The group came together as a way to sustain the work and research development of both the doctoral students and the junior faculty in the collective.

Keywords: critical pedagogy, research collective, teacher education, culturally sustaining pedagogy
\end{abstract}




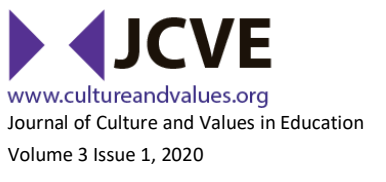

Journal of Culture and Values in Education
Morales Morales, D., Ruggiano, C., Carter, C., Pfeifer, K. J., \& Green, K. L., Disrupting to sustain: Teacher preparation through innovative teaching and learning practices

\section{Introduction}

In Teaching Community: A Pedagogy of Hope, bell hooks (2003) asked, "are educational institutions ready to teach us something new? Are students ready to learn something new?" (p. 2). She is not asking about new teaching techniques, or strategies for tackling standardized testing; hooks is likely questioning if educational institutions are ready to teach students the tools that will break systems of oppression. She is interrogating institutions, and reminding them of their duty to allow people to become fully human. In an effort to respond to this question, and in an attempt to challenge the way teaching and research is done, this essay describes the organization, functioning, and theoretical standpoints of the Critical Education Research Collective (CERC). The CERC is a critical inquiry group that seeks to disrupt and transform traditional, normative practices in an English Methods course offered at a higher education teacher preparation program while also disrupting the traditional ways in which doctoral students are advised to conduct research at a top tier research institution.

The CERC is composed of one junior faculty member and four doctoral students from across departments and disciplines with shared research interests and experiences focused on cultivating critical pedagogy in the teacher education classroom. The collective originally began as a research seminar, Critical English Education Research Collective (CEERC), for doctoral students interested in thinking, reading, and conducting research about social justice, equity, and access in the context of English Language Arts (teacher) education. We examined scholarship related to critical English education and worked with Dr. Green, a pretenured faculty member, to write an IRB and design a research study involving our preservice English Language Arts (ELA) teacher candidates. After the first year of working closely on this research project we decided to formalize our work and became recognized as a formal collective by the graduate student senate. This transition included our original aim to focus on the context of ELA teacher preparation and was further expanded to explore and examine critical approaches to education more broadly, thus resulting in the change in our name to CERC. This paper will focus on how we enacted collaborative approaches specific to the ELA strand of our research interests.

Our practice is aimed at how we, as a pre-tenured faculty member and doctoral students reflect on our work and nurture socially just kindergarten-12th grade (K-12) classroom practices frequently centered in teacher education literature pertaining to learning in urban contexts (Duncan-Andrade, 2004; Duncan-Andrade \& Morrell, 2008; Emdin, 2016; Matias, 2013a, 2016; Picower, 2012). Additionally, we grapple with how this important work -- and obstacles to its practice -- should be equally considered and implemented in rural and suburban school communities- Regarding our interest in social justice education within the context of the English Language Arts classroom, we seek to attend to sociocultural issues and inequities related to race, ethnicity, language, class, gender, ability, and sexuality. Within this context, our goal is to enact pedagogies that cultivate critical, multi-literacy skills aimed toward helping students both change their material circumstances and act as change agents within the broader contexts of their communities and society. Because some members of our collective are situated within the 


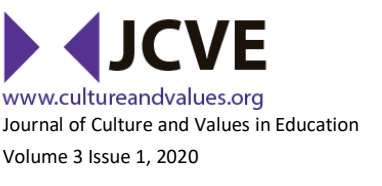

Morales Morales, D., Ruggiano, C., Carter, C., Pfeifer, K. J., \& Green, K. L., Disrupting to sustain: Teacher preparation through innovative teaching and learning practices

teacher education program and others within the social justice program, our work is uniquely positioned at the intersection of higher education and K-12. These areas of research align in important ways to address the varying needs of our teacher candidates who are preparing to teach in different contexts (i.e., urban, suburban, and rural). In all of these contexts, they face similar challenges, such as tailoring curriculum to student interests and facilitating classroom situations that require encounters and learning across lines of social difference including race, ethnicity, gender, sexuality, class, ability, and language. The convergence of our research interests and areas of expertise within the CERC afford us the opportunity to contribute ideas, approaches, and knowledge that address these challenges of teaching for social justice in varying and nuanced ways.

Zadja, Majhanovich, and Rust (2006) claim that social justice is "based on the principles of equality and solidarity, that understands and values human rights, and that recognizes the dignity of every human being (p. 1). Social justice education and teaching provides the distinct advantage of addressing educational and social disparity through equity driven approaches in and out schools. As a collective, we are learning how to address the diversity of our teacher candidates' teaching contexts so that our discussions of socially just classroom practices readily address secondary student learning needs, experiences, and interests. However, we also face challenges given the larger context of education in US public schools and higher education institutions. For example, within teacher education, obstacles to teaching for social justice include: a state-mandated focus on the standardization of content knowledge and the performance of skills; challenges to Ethnic Studies curricular content that prioritizes the raising of critical consciousness through centering the lives of Black, Indigenous and People of Color (BIPOC); access to intersectional and collaborative relationships between faculty, students, and pre-service teachers; and limits of academic support in higher education that occur as the result of siloed and individualistic practices - practices that can often act as a barrier to supportive and interdisciplinary approaches.

These challenges remind us that schools are sites of social, cultural, and economic reproduction, and teachers play a pivotal role in aiding or disrupting this process. The reproductive aspects of schooling are particularly harmful because they work to reify hegemonic epistemologies and ontologies in educational spaces which then make invisible and silence already marginalized voices both in the classroom and on syllabi (Cook-Sather, 2002). To disrupt this process, it is important to look at the ways in which teacher training and professional development in both higher education and $\mathrm{K}-12$ settings is constructed. The content and methodologies of such training varies but in some cases teachers are trained to teach to the test and therefore do not support students in developing the skills needed for higher education and civic engagement (Darling-Hammond, 2010; Mirra \& Garcia 2017). Two of our goals as a critical inquiry group are to explore what happens when educators come together through an equity-based model of teacher-researcher training and to explore what impact this model has on our classrooms and our practice as education researchers.

In this essay, we describe how the CERC meetings were structured in an effort to develop and engage participants in social justice teaching and humanizing research. Moreover, we provide insights into participants in a teacher-researcher led inquiry group 


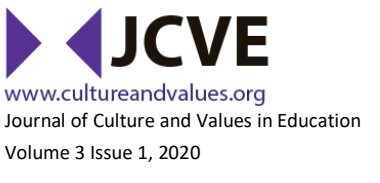

Morales Morales, D., Ruggiano, C., Carter, C., Pfeifer, K. J., \& Green, K. L., Disrupting to sustain:

Teacher preparation through innovative teaching and learning practices

and how this group begins to shift the conversation about teacher-researchers beyond the binary of effective and ineffective to a more nuanced understanding of our practice as always in a process. This echoes Nieto's (2003) notion of teacher development where she claims, "excellent teachers do not emerge full blown at graduation; nor are they just 'born teachers.' Instead, teachers are always in the process of 'becoming'" (p. 395). In the following section, we share more about the creation of our collective and we introduce our members. We describe our experiences in education, the reasons we joined the CERC, and our research interests. The connections among and between us constitute our collective, inform our work, and transform the ways in which we are becoming teacher-researchers.

\section{The CERC as a Social Justice Academic Space}

The CERC was created, housed, and operated in the College of Education. All CERC members are social justice educators who, prior to our doctoral work, were either earlycareer or veteran educators. We were invited by a junior faculty member to be part of a research group that would study teacher education. This group would also help each member navigate and refine our respective research journeys. Our past teaching and research experiences informed our desire and need to continue working with like-minded colleagues who are able and willing to support one another's political and social justiceoriented pedagogy development as teacher-researchers.

The CERC provided a space to connect our growing research interests with classroom practices, which deepened the group's understanding and conceptualization of social justice practices and created a collective space for critical discourse and reflection. Each CERC meeting regularly included three parts: 1 ) individual personal and academic trajectories check-ins, 2) theoretical and/or pedagogical readings and discussions, and 3) curriculum or theoretical discussions. These three parts were geared towards having group members engage in reflection, theory, and practice, and through this process, aimed to welcome our individual humanity, hold members accountable in nurturing and supportive ways, and invite materials and concepts from a variety of theoretical perspectives. Ultimately, this process and approach translated into the creation of a safe space for asking questions and grappling with new ideas; it also acted as a counter space that mitigated the overwhelming presence of whiteness experienced in many of our more traditional graduate courses.

\section{Positionality of the Authors}

Because "the biographical journeys of researchers greatly influence their values, their research questions, and the knowledge they construct" (Banks, 1998, p. 4), we consider our journeys and varying positionalities as always in direct relation to our work and our process of becoming teachers and researchers. We deeply value the individual knowledge and experiences that each CERC member possesses and work intentionally to incorporate them as essential building blocks into our individual and collective endeavors and frames of understanding. 


\section{Cee Carter}

Cee's current research informs teacher practice using participatory research methods that highlight student feedback and experiences in schools. Cee's work is also shaped by her former experiences in public schools as a math teacher and as a professional in non-profit education reform. These experiences exposed the racial, economic and gendered processes that impact education for young people of color in urban settings. Therefore, in her work, she applies the critical lenses of radical black feminism and racial capitalism to highlight how power structures operate, persist, and position student learning and experiences in public schools. Cee joined the CERC as a first year doctoral student to build and learn from a community of critical education scholars as well as learn about the research process from a critical, decolonizing perspective.

\section{Dr. Keisha L. Green}

Keisha is interested in critical teacher education, youth literacy practices, and humanizing qualitative research. As an assistant professor working with Secondary English Language Arts pre- and in-service teachers, she is collaboratively building a communityengaged and field-based teacher preparation experience. Her scholarship and teaching in the areas of critical literacy, critical pedagogy, and youth literacy practices demonstrate her commitment to working for equity and racial justice in education. In particular, Keisha's research centers youth voice, identity, and multiliterate lives of young people of color, as well as documents white pre-service teachers' perception of themselves in relation to their culturally and linguistically diverse students and about how these same teachers incorporate principles of social justice and culturally sustaining pedagogies into their curricular content and instructional practices. Broadly, Keisha is interested in creating more opportunities to support pre- and in-service teachers through university-school-community partnerships. Starting the CERC was an attempt to work collaboratively with doctoral students engaged in similar work as a way to demystify the academy and democratize knowledge production.

\section{Daniel Morales Morales}

Daniel grew up and attended school in a rural, working-class community in Chile under dictatorship. He completed his vocational schooling in a neighboring city with the goal of having a job that would pay more than his mom's occupation as a maid. College was not an option until his family realized that a college degree was needed to have a stable income. After quitting a business program, Daniel decided to pursue a teaching degree. Although he never worked as a teacher at a public school, Daniel had the opportunity to study a semester in the U.S., and then pursued his Master's degree and doctoral studies in Maryland and Massachusetts, respectively. Daniel's interest in teacher training comes from his work with low-income and first-generation college-bound students. He joined the CERC to continue learning about critical literacies and methodologies and to organize and study with likeminded folks. 


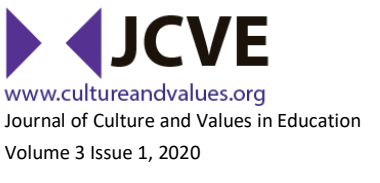

Morales Morales, D., Ruggiano, C., Carter, C., Pfeifer, K. J., \& Green, K. L., Disrupting to sustain:

Teacher preparation through innovative teaching and learning practices

\section{Dr. Kimberly J. Pfeifer}

Kimberly's current research includes working with preservice teachers and developing curricula centered on disrupting gender inequities in educational spaces. Through this work, she examines the intersecting roles of gender, race, class, and age in order to better understand enactments and experiences of educational sexism. Before pursuing a Ph.D. focused on gender equity, Kimberly was a middle and high school ELA teacher of emerging bilingual and multilingual students. Her pedagogical practice is rooted in culturally responsive and sustaining teaching, critical literacies, and interdisciplinary curriculum design. As a member of the CERC, Kimberly has been able to meaningfully integrate her experiences as a K-12 educator and interest in teacher education, alongside the cultivation of a deepened understanding of critical pedagogy.

\section{Carie Ruggiano}

Carie's current research is focused on understanding and improving the schooling experiences for youth of color and their families in predominantly white, rural settings through critical and culturally sustaining approaches to teaching and learning. This interest is rooted in more than two decades of experience as a middle and high school English Language Arts teacher and is deeply inspired and driven by the experiences of her own children, who navigate predominantly white schooling and community spaces as young men of color on a daily basis. Carie came to teaching with an orientation grounded in social justice approaches. This orientation would guide her praxis in K-12 classrooms and schools; and, now, informs her work with the preservice teachers whom she supervises and mentors in their development toward critical and culturally sustaining teaching. Carie is dedicated to efforts to recruiting, preparing, and supporting teachers committed to transformative and liberatory approaches, especially in the English classroom. Her membership in the CERC has allowed for deepened understanding among a community of fellow critical scholars who support the consideration and implications of applying this important work in rural contexts.

\section{The CERC as a Collective Critical Inquiry Group}

There are various types of collaborative groups that engage in teacher inquiry-e.g., teacher research communities, study practice groups, professional development schools, inquiry groups, and critical inquiry groups (Cochran-Smith \& Lytle, 1993, 2009). A critical inquiry group involves a collective of educators who "work to powerfully address the needs of their students while they engage in their own professional growth" (Duncan-Andrade, 2004, p. 340). Similarly, Cochran-Smith and Lytle (2009) use the term "practitioner inquiry" and claim that practitioner research is "a valuable mode of critique of the inequities in schools and society and of knowledge hierarchies within as well as beyond the local context" (p. ix). Just as teaching is both a social and political endeavor (Aronowitz \& Giroux, 1993; Giroux 1988; Paris \& Alim, 2017), a critical inquiry group as a model for teacher/researcher development can begin to challenge hegemony and hierarchies of power at school sites and Universities (Andrews et al., 2017; Cochran-Smith \& Lytle, 1999; Duncan-Andrade, 2005; Picower, 2007). 


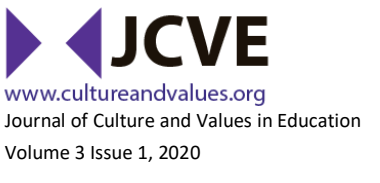

Morales Morales, D., Ruggiano, C., Carter, C., Pfeifer, K. J., \& Green, K. L., Disrupting to sustain:

Teacher preparation through innovative teaching and learning practices

A critical inquiry group is an ongoing effort to learn, collaborate, and explore different ways to implement critical pedagogy. It is also a space to contemplate theory and locate theoretical implications that can be used in the transformation of classroom practices. Challenging hegemony is at the foundation of an inquiry approach (Cochran-Smith \& Lytle, 1999; Duncan-Andrade, 2005; Picower, 2007) because it "involves making problematic the current arrangements of schooling; the ways knowledge is constructed, evaluated and used, and teachers' individual and collective roles in bringing about change" (Cochran-Smith \& Lytle, 1999, p. 18). Duncan-Andrade (2004) observes that the critical in critical inquiry group draws from the scholarship of Paulo Freire which includes critical "dialogue, reflection, and praxis" (p. 341). Within this practice, learning and teaching can begin to take Freirian attributes of respect and mutual dialogue where people are humanized and knowledge production is encouraged. Critical inquiry groups are also humanizing spaces where knowledge production is encouraged, making respect and mutual dialogue central attributes for such groups. In their discussion of critical inquiry groups, Nieto and colleagues (2002) emphasize that its humanizing aspects support the work of educators.

We conceptualize our work within this collective critical inquiry group as both disruptive and sustaining. Given that the CERC is situated within the broader institution of formal education and housed within a college of education at a large, flagship university, its disruptive potential is located at the intersections of its purpose, structure and related activities, and practices. First, its purpose is to disrupt traditional approaches to teacher education and researcher training to center social justice. Next, the structure and activities that we participate in diverge from what is typically considered the norm in formal (higher) education, norms which often follow a professor-student model of teaching, learning, and mentorship. Through the CERC, Dr. Green invited and nurtured doctoral students' individual and collective knowledge(s), expertise, and varied, but intersecting, fields of research. Her mentorship was not limited to the space of the CERC; it also extended into the English Methods course, where she gave us opportunities to shape the graduate education classroom. In this way, our teaching and learning activities were both altered and transformed, illuminating the implications of developing and sharing critical knowledge(s) in formal educational spaces.

As a critical inquiry group of teachers and educational researchers, we inhabit a space of becoming as we draw on each other's experiences and knowledge to strengthen our individual and collective work. Through the CERC, we have not only been apprenticed into the field of educational research, but we have also challenged and critiqued traditional approaches to teaching and research within this field. The opportunity to challenge and critique traditional approaches, has transformed our individual and collective practice by encouraging us to notice and interrupt the ways in which we might be complicit with practices that decenter humanization for the sake of university priorities. Therefore, we regularly prioritize engaging with theory to inform our thinking, and practice of research and teaching. In the following section, we share about the theories that have informed our thinking and transformed our work. Our work in undergraduate and graduate education studies classrooms and the CERC is nested in a larger conversation about socially just practices for K-12 classrooms. Thus, the theories we discuss inform how we introduce 
socially just content and practices to English teacher-candidates. We also describe how the theories we draw on inform our work with each other as teacher-researchers in the College of Education.

\section{Theoretical Standpoints}

The following theoretical standpoints guide our work as educators, researchers, and CERC members. They also illuminate how educators (re)build inclusive classroom spaces that center the experiences of low-income and working-class students of color in K-12 classrooms. Because our work and interests are positioned at the intersection of K-12 and higher education, we imagine that the approaches that we take to conducting research in the space of a critical inquiry group and the implications of what it means to enact critical, culturally sustaining, and decolonizing pedagogies as being equally important and translatable to both contexts. In the context of these reimagined spaces, educators work to unveil societal oppression, provide space for dialogue, empower and demonstrate care for marginalized youth, and engage in political development.

\section{Teaching for Social Justice}

Social justice education (SJE) extends as far back as the era of enslavement with selfeducation and literacy movements among African Americans, the Common School Movement of the 1830s, and 20th century thinkers such as Dewey, Dubois, and Woodson (Spring, 2013). However, SJE was recognized and formalized in schools of education in the 1990s. Today, SJE is found in university courses and programs, K-12 teaching, curriculum and program design (Adams et al., 2007). Teaching for social justice is a pedagogical approach in and out of the classroom that works to address systemic inequity (e.g., related to race, ethnicity, language, gender, sexuality, ability, and social class.) through academic and critical literacy, towards social action (Duncan-Andrade \& Morrell, 2008; Picower, 2012). Social justice teaching is an umbrella term that encompasses various theories and pedagogies such as critical pedagogy, critical race, culturally relevant and sustaining pedagogies, decolonizing pedagogies, ethnic studies, feminist, and social justice pedagogy (Adams, 2007; Chapman \& Hobbel, 2010; Picower, 2012).

Social justice teaching provides an academically rigorous curriculum that examines oppression and empowers marginalized students, tends to individual students in a nurturing and caring manner and extends learning beyond the classroom (Duncan-Andrade \& Morrell, 2008; Picower, 2012). Educators' capacity and willingness to enact teaching for social justice has historically been impacted by a political climate that dismisses equity-based pedagogies. Moreover, social justice educators are often forced to either teach in a state of fear, compromise their social justice beliefs, or leave the classroom entirely (Lipman, 2009; McNeil, 2009; Sleeter, 2012). For educators working towards social justice, it is important to engage students in an analysis of social injustices, provide spaces for reflection and dialogue, and support their development of critical consciousness in order to recognize their humanity and collaborate towards our collective liberation and social transformation (Matias, 2013b). 


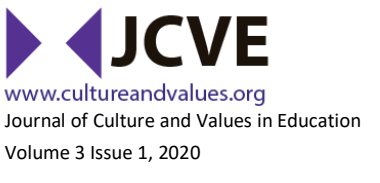

Morales Morales, D., Ruggiano, C., Carter, C., Pfeifer, K. J., \& Green, K. L., Disrupting to sustain:

Teacher preparation through innovative teaching and learning practices

\section{Critical Pedagogy}

Critical theory of education was born out of the need to understand how hegemony, masked in education policy, curriculum, and assessments, marginalizes and/or silences students, especially those from working-class backgrounds (Duncan-Andrade \& Morrell, 2008; Freire, 1970). Critical pedagogy originated from critical theory as a tangible, on-theground method of undermining oppressive schooling structures. Freire's (1970) concept of critical refers to a problem-posing, self-reflective, and dialogic pedagogy that aims to transform oppressive systems. Freire also argued that praxis, or "reflection and action directed at structures to be transformed" (p. 51), can lead both oppressors and the oppressed to develop a critical consciousness (or conscientization) about the self, others, and the world. Through this (new) naming of the world, those whose voices have been historically silenced (i.e., the oppressed) can subvert stories and realities that are socially constructed (by the oppressors) and often deficit-based (DeJong \& Love, 2015). Central to understanding critical pedagogy is the idea that there is a need for education to challenge social domination while developing critical literacy skills (Freire, 1970; Freire \& Macedo, 1987). This critical theory of education centers the importance of understanding how hegemony marginalizes students, especially those from working-class backgrounds (Freire, 1970; Duncan-Andrade \& Morrell, 2008)

Broadly, enactments of critical pedagogy create and invite space to cultivate the skills for educators and students to engage in the multi-faceted nature of social justice education. As such, these concepts are deeply interconnected and always in relationship to each other. Foundational characteristics of critical pedagogy include: working towards social justice in and out of school spaces; creating democratic and healing spaces in education; developing conscientization; deconstructing power, privilege and positivistic notions of knowledge; and engaging teachers and students in a praxis of theory and practice (Akom et al., 2008; Duncan-Andrade \& Morrell, 2008; Darder et al., 2009). Critical pedagogy is used to name and examine the ways in which state and institutional structures act as mechanisms of cultural and economic reproduction. Through an understanding of how power maintains itself, we can see that transforming educational institutions as necessary if we are to impact all aspects of society to one which is grounded in equity, love, and healing (Battiste, 2004).

\section{Culturally Sustaining Pedagogies}

In her highly influential work, Gloria Ladson-Billings (1995) proposed a culturally relevant pedagogy (CRP), aimed at the reformation of teacher education, specifically with regard to educating teachers for successful teaching with African American students. Such an approach emphasizes teacher praxis and the co-construction of learning communities and environments that both understand and draw on students' unique personal and cultural strengths. Ladson-Billings (1995) proposed three goals on which CRP practices were grounded. First, teaching must yield academic success. Second, teaching must help students develop positive ethnic and cultural identities while simultaneously helping them achieve academically. Third, teaching must support students' ability "to recognize, understand, and critique current and social inequalities" (p. 476). 
Morales Morales, D., Ruggiano, C., Carter, C., Pfeifer, K. J., \& Green, K. L., Disrupting to sustain:

Teacher preparation through innovative teaching and learning practices

Paris (2012) extended Ladson-Billings' work further in his conception of culturally sustaining pedagogy (CSP), which seeks "to perpetuate and foster-to sustain-linguistic, literate and cultural pluralisms as part of the democratic process of schooling" (p. 95). Doing so demands that teachers must commit to the development of knowledge(s) beyond their own, while simultaneously engaging in a practice of critical self-reflection - characteristics which are centered in notions of critical and CSP. Important aspects of the ideological departure from CRP include, 1) an explicit focus on the plural and the evolving nature of youth cultural activity, and 2) a commitment to youth culture as holding counterhegemonic potential, though always in need of critical introspection (Paris \& Alim, 2017).

\section{Decolonizing Pedagogies}

As a response to the logics of imperialism and settler colonialism, decolonizing pedagogies refers to approaches and practices educators and researchers might use to refuse or disrupt complicity in viewing each other, the land and knowledge as property (Smith, 2012). In Decolonizing Educational Research (2016), Leigh Patel argues that this way of viewing each other, the land and knowledge has had "material effects for learning, learners, and research" (p. 71), which can be seen in the traditional ways we practice education and educational research. Patel especially pays attention to how Black, Indigenous, Latinx, and Asian students are heavily subject to educational intervention based on regular comparison to white students' achievement scores. Tuck (2009) argues that we might suspend the ways in which we rely on documenting narratives of damage and pain in our research, and instead opt to place a "moratorium on damage-centered research" to accomplish three goals: revisioning theories of change, establish tribal and community human research ethics guidelines, and create mutually beneficial roles for academic researchers in community research (pp. 423-424). However, Tuck and Yang (2012) warn that decolonization is not a metaphor as seen in intentions to decolonize our classrooms. For Tuck and Yang, decolonization as a metaphor weakens the aim of the concept of decolonization by rewriting settler innocence, or the sense that if we just do decolonization, then we don't have to radically alter the structures that have created the settler state in which we live.

Additionally, Tuck and Yang (2012) describe decolonization as an "elsewhere" and a concept that unsettles us and "offers a different perspective to human and civil rights based approaches to justice" (p. 36). Since decolonization is not a metaphor, decolonizing pedagogies can only refer to the ways in which educators and researchers are attempting to acknowledge and draw attention to how the logics of settler colonialism continue to situate land, knowledge and people as property to be owned. Further, Tuck and Yang (2014) argue that researchers might opt for refusal in research, or attempting "to place limits on conquest and the colonization of knowledge by marking what is off limits, which is not up for grabs or discussion, which is sacred and what can't be known" (p. 225). Refusal then becomes a way of pausing to acknowledge how settler colonialism impacts our work and a way of being intentional about how to participate and situate our research (Tuck \& Yang, 2014; Patel, 2016). In sum, decolonizing pedagogy is in conversation with a history of imperialism, settler colonialism and how these realities have shaped and situated land, people and knowledge. It 
Morales Morales, D., Ruggiano, C., Carter, C., Pfeifer, K. J., \& Green, K. L., Disrupting to sustain:

Teacher preparation through innovative teaching and learning practices

is an attempt to notice and name this history in our pedagogical and research practices and calls on us to refuse traditional ways of doing, being and knowing.

These theoretical standpoints represent the principles in which we anchor our approaches to social justice education, both in how the Methods course and the CERC are designed and enacted. The tenets of critical, culturally sustaining, and decolonizing pedagogies guide the ways in which we engage with our individual and collective research projects and how we (re)imagine the role of English teachers, teacher educators, and students as part of a broader sociopolitical context. Finally, these principles inform and remind us of a desired way of being and are woven into the ways that we come together and learn from one another, as people deeply committed to equity, transformation, and liberation in and beyond educational settings. The following section serves to illuminate how we work to apply these theories to our always-developing practice.

\section{The CERC's Process of Becoming}

In the early stages of the CERC, Dr. Green invited us to join a research project involving her English Methods course in the College of Education. Dr. Green's invitation was extended to us as part of her regular praxis of reflection as a scholar-activist and teacherresearcher. Committed to social justice teacher education, Dr. Green reflects on ways her English Education classroom can invite opportunities for teacher-candidates to reflect on the political nature and practice of teaching. The ways in which we chose to implement and collaborate on this project not only supported us to regularly meet and establish ourselves as a collective, but also provided the opportunity for us to reflect on our praxis as becoming teacher-researchers. In this section, we describe how we engaged in theory through our CERC meetings and how we allowed our engagement with theory to shape practice in the graduate education classroom. These practices informed how we worked with one another, transformed our individual and collective teaching and learning activities, and illuminated the implications of developing and sharing critical knowledge(s) in formal educational spaces. In this section, we address these implications through a discussion of collective observation, praxis oriented engagements, student led research, shared facilitation, sustaining and enhancing social justice, and humanizing classroom culture and research practices.

\section{Collective Observation}

For the English Methods research project, the members of the collective decided to be both participants in and observers of the English Methods course. We acted as participant observers in an attempt to document what was happening and what was said in the course and in teacher-candidate practicum classrooms. Overall, our observations and discussions focused on the sociopolitical context of teaching, and how the CERC was supporting, enhancing, or discouraging social justice teaching. The CERC doctoral students participated in the course by joining class each week; getting to know the English teachercandidates; contributing to class discussions; providing feedback on lesson plans; giving presentations based on our areas of educational expertise and research interests; and, 
Morales Morales, D., Ruggiano, C., Carter, C., Pfeifer, K. J., \& Green, K. L., Disrupting to sustain: Teacher preparation through innovative teaching and learning practices

journaling in response to class prompts. Additionally, we participated in the course as observers, noting how the class discussion moved, the gender dynamics present, teacher candidates' expressed concerns and challenges, discussions about students, and other notes that helped us identify opportunities to shift or add to the conversation about social justice education and the political nature and practice of teaching. We also observed teacher candidates in their respective middle and high school teaching practicum placements to understand how, if at all, teacher-candidates were becoming social justice educators outside of the graduate education classroom. Moreover, as a group, we reflected about our own participation in the methods course after each session to determine how to structure the next week's class. As the CERC, we also collaborated on the structure and agenda of our member meetings. Our collective met regularly to discuss theory, our individual research endeavors, share updates about our progress on the collective research project, and reflect on our observations of the course. Additionally, we suggested scholarly articles, books, and media for our collective and the methods course to engage and discuss.

In the primary space of the English Methods class we were able to hear, observe, and understand the way student teachers were processing what was occurring in the methods class. In addition to our participant observation, we gathered and provided feedback on teacher-candidate journals in which they responded to prompts about assigned readings, class discussions, and their practicum experience(s). Through this role and our critical inquiry, we were able to learn pre-service teachers' perspectives, lessons, frustrations, as well as opportunities for social justice education within both the English teacher-candidate group and their teaching practicum spaces. These perspective-gaining exercises helped us decide how and when we introduced social justice material as well as how to structure class to address the needs of the teacher-candidates. For example, Carie gave a presentation about how to develop an English unit for To Kill a Mockingbird (Lee, 1982) after students expressed a desire to learn more about how to apply our discussions about social justice to the English classroom. Carie's presentation addressed the need for a pedagogical skill by offering examples of lessons and activities teacher-candidates could use to create a unit. Her presentation also incorporated additional texts such as images, videos, and further readings to illuminate the contours and histories of racism and resistance during the time of the novel and in the present-day U.S. and to center the voices of people of Color through the incorporation of counter-storytelling.

In the secondary space of this critical collective, members discussed their observations, questions, challenges, and opportunities to use their expertise to make sense of the English Methods class. Some of these discussions centered around how Whiteness, in particular, showed up in the English Methods course, especially with regard to how preservice teachers made sense of and either internalized or resisted the implications of their racial identity on their pedagogy. We also held conversations about our own research trajectories and how they intersected with the English Methods course. A big part of our dialogue as a collective focused on how student teachers and doctoral students were merging academic and critical literacies, developing professional identities, and providing opportunities for reflection and action. We view this approach to praxis (reflection and 
Morales Morales, D., Ruggiano, C., Carter, C., Pfeifer, K. J., \& Green, K. L., Disrupting to sustain:

Teacher preparation through innovative teaching and learning practices

action) and the co-construction of knowledge and learning as enactments of the critical and culturally sustaining theories that guide our work.

\section{Praxis-Oriented Engagement}

In addition to the CERC space being a social justice space, the CERC was also a praxisoriented structure that engaged doctoral students in political and pedagogical development. The readings in the CERC space included topics on decolonizing pedagogy, ethnic studies, critical race theory, critiques of neo-liberal education, critical pedagogy, and youth participatory action research. Some of the readings were collectively agreed on and aimed at improving both our teaching and research practices. These readings and discussions provided members from the CERC the opportunity to intellectualize our teacher-research practice. During the CERC meetings, we often discussed how we were regularly thinking about our teaching and practice and our facilitation of the English Methods class provided a distinct opportunity for us to implement and improve our own praxis. Each CERC member possessed different teaching expertise and research interests, so this allowed us to engage with the student teachers in varied ways and model the enactment of socially just lessons and units across intersecting interests of race, gender, and language.

Our audience -- the student teachers -- also benefited from this collaborative approach. In exit interviews and transcripts from class discussions, several students reflected on the benefit of learning more about theories and practices related to culturally sustaining pedagogies applied to their practice as developing ELA teachers. Specifically, they named the importance of incorporating multiple perspectives into one's teaching practice. From a learner's perspective, they reflected on the importance of class sessions that invited the voices of educators in the field enacting culturally sustaining pedagogy, and those of local students who attended two class sessions to share their educational experiences as young people of color. In addition to the students who attended schools in urban communities, many of our student speakers also attended predominantly white rural or suburban schools. Coupled with their engagement with materials from the Methods course that invited counterstories (Solorzano \& Yosso, 2002), these experiences worked to help solidify a more embodied understanding of how critical and culturally sustaining pedagogy can be enacted. In turn, several of the teacher candidates attempted to replicate some of our class activities with their own students. Additionally, by bringing voices in from both academic and local communities, we aimed to further demonstrate approaches to centering often silenced and minoritized voices in the context of the classroom (Mitra, 2003; Stauber, 2017). Such approaches not only offer concrete examples for how teachers can disrupt traditional practices, but also served as a model for how and why affinity spaces can be created and sustained. Affinity spaces are especially important and beneficial, particularly for students of color attending predominantly white schools.

\section{Legitimizing Collaborative Doctoral Student-Led Research}

Understanding the process of a collaborative critical doctoral student-led inquiry group, like the CERC, as legitimate research begins to shift the paradigm of who is seen as a producer of knowledge in the field of education. Through an interrogation of our teaching 
Morales Morales, D., Ruggiano, C., Carter, C., Pfeifer, K. J., \& Green, K. L., Disrupting to sustain:

Teacher preparation through innovative teaching and learning practices

and research, we, as educators and researchers begin to establish ourselves within the teaching and research profession as capable of learning about ourselves through a research process. Taking an active and democratic role in developing our own practice shifts the balance of power which, in traditional practices, often lies with the teacher or professor as expert, and doctoral students as learners. What stands out in our becoming as educators, researchers, and doctoral students is that we have the potential to put forth research that does not "emanate solely from theory nor from practice, but from critical reflection on the intersection of the two" (Cochran-Smith \& Lytle, 1990, p. 6).

\section{Shared Facilitation}

Different from other types of teacher development (i.e., school-based professional development, curricular workshops, and teacher preparation programs), the CERC was a doctoral student/teacher-led and facilitated space. The CERC members collaborated with Dr. Green to lead and facilitate sections of the teacher-candidate English Methods course. We also collaborated to lead and facilitate the collective's research meetings while addressing concerns related to our social justice teaching and practice in urban, suburban and rural schooling contexts. In addition, the CERC's structure approximated a horizontal leadership model, where doctoral students had a say in the decisions being made about the classroom and the research project. The space was created and organized to draw strengths from its members. This orientation allowed the group to determine the focus of the space and how best to develop ourselves pedagogically.

Facilitation also played a key role for maintaining an inclusive collective space, or one in which we prioritized sharing responsibility and embracing multiple perspectives.

Throughout the CERC meetings, members were encouraged to facilitate sections of the meeting, such as the check-ins, reading discussions, or the research discussions. In this shared space, multiple voices and perspectives were included to ensure that it reflected the various needs and perspectives of its members, which invited consideration of the diversity of student identities and knowledge that pre-service teachers will ultimately encounter, and we hope, nurture and sustain (Paris \& Alim, 2017). Through shared facilitation, the CERC created a cycle of teaching, learning, planning, implementing, and reflecting that was continually informed by this cycle.

\section{Sustaining and Enhancing Social Justice}

The CERC members benefited from the collective because we were able to trust our mentor and our peers. We were at times vulnerable with each other, we had to collaborate and were held accountable in the contexts of our teaching and research practices. The trust, vulnerability, collaboration, and accountability are interdependent components of a model of teaching and mentoring that can be described as a sustaining and enhancing social justice teaching (Paris, 2012; Patel, 2016). The CERC space was disruptive to traditional approaches to research and teacher education and distinct from individualistic, top-down practices that don't allow for the individualized support, reflexivity, and opportunities to collaborate through shared knowledge that we routinely experienced. The CERC members voluntarily gathered and still gather in an academic space where we are able to share our political and 
Morales Morales, D., Ruggiano, C., Carter, C., Pfeifer, K. J., \& Green, K. L., Disrupting to sustain:

Teacher preparation through innovative teaching and learning practices

pedagogical views and agendas freely. We view this willingness to meet and engage and the creation of a safe space for sociopolitical conversation as further evidence of the possibilities inherent in sustaining disruptions within academia. A key aspect for the development of teachers is that teachers possess or develop political and ideological clarity. However, often, teaching spaces and meetings might not provide an opportunity to have critical conversations about pedagogy and politics. Bartolome (2004) claims that if teachers have political clarity, they will then be able to walk students through the steps of developing their own political consciousness as they interrogate how specific ideologies function in relation to power.

Trust was also a critical factor to be vulnerable. The structure and membership of the collective modeled vulnerability while providing a space for honest dialogue. We positioned social justice as an ongoing process of reflection and action, which required us to be vulnerable with one another, which in turn, pushed us to articulate both our teaching and research practice and then look to the group for support. We relied on each other to grow and learn. Accountability served as a way to support and sustain our teaching for social justice. We held ourselves accountable by allowing our meetings to serve as learning spaces where we gave each other feedback about areas of improvement in teaching or research practices. We debriefed after every session of the English Methods class and provided each other with constructive feedback about lessons we prepared for the class. We developed our sense of accountability, with regard to individual and collective research practices, through our involvement in each other's lines of inquiry and development of ethical research questions and methods. We also challenged ourselves and each other to more deeply understand and anchor our work in critical and culturally sustaining pedagogies by engaging in shared critical introspection to regularly ask how if, at all, we were continuing to perpetuate traditional approaches to teacher education and research and how we might disrupt those approaches (Paris, 2012; Paris \& Alim, 2017). For example, Kimberly and Cee often brought this question up when debriefing the CERC activities in their joint car rides to and from observations and other academic engagements. In one instance, they asked how a desire to support teacher candidate morale in their early stages of pedagogical development often prompts feedback that fails to consider or center the political nature of teaching and instead solely centers notions of best practice modeled after state teacher evaluations.

\section{Humanizing Classroom Culture and Research Practices}

According to Freire (2000), a humanizing process can transform education into a practice of freedom, where students and teachers are complete human beings. San Pedro and Kinloch (2017) extended notions of humanizing praxis to researchers, calling on engagement in Projects in Humanization $(\mathrm{PiH})$ that center the relationships and experiences we share with one another in ways that emphasize our mutual desires for social justice in schools and communities, as well as in our professional and personal lives. Projects in Humanization $(\mathrm{PiH})$, they posit, are enacted primarily through "dialogic engagements" ( $p$. 374). For the CERC, the idea is, that if pre-service teachers are engaged in a humanizing process, they, in turn, will humanize their students. However, this is a challenge if teachers 
Morales Morales, D., Ruggiano, C., Carter, C., Pfeifer, K. J., \& Green, K. L., Disrupting to sustain:

Teacher preparation through innovative teaching and learning practices

have not had the opportunity to experience what a humanizing, democratic, liberatory education space looks and feels like.

Given that Freire (2000) describes humanization as the struggle to understand the conditions that make us oppressed and then work to change those conditions, and San Pedro's (2017) centering of relational dialogue, the CERC proved to be important in its ability to nurture group dialogue across and at the intersections of our identities and scholarly interests. In turn, we were left with a feeling of being seen, heard, and valued and benefited immensely from the storying and sharing that transpired. Applied to the English Methods course, this humanizing approach provided the pre-service teachers with a space to meet, talk, listen, and challenge the isolation and alienation that they sometimes felt at their school sites and their academic spaces while simultaneously developing caring and supportive relationships with the CERC participants.

Similar to Jones (2014), the collective critical inquiry provided support for the educator-researchers, who are also the authors of this piece, to find new meaning for our pedagogical and research possibilities. For example, Kimberly developed an anti-sexist curriculum as part of her comprehensive exam requirements, which she later implemented as a series of workshops for pre-service teachers in her dissertation study. Daniel is supporting a mentoring initiative for teachers of color and American Indigenous teachers interested in ethnic studies in Minnesota. Cee is in the early stages of theorizing a methodological stance she calls pivoting, or a space of becoming in which one reckons with complicity and embraces the need to shift in the direction(s) of new learning. Carie is currently developing a dissertation study aimed to facilitate an intervention utilizing digital storytelling as a tool for helping majority-white English teacher candidates engage in critical self-reflection and examinations of whiteness as part of their development toward culturally sustaining and anti-racist pedagogies. Overall, this collaborative, critical inquiry group has helped us reimagine relationships between faculty, doctoral students, and student-teachers and our individual and collective work.

\section{Conclusion}

This essay is informed by our experiences as doctoral students, teacher educators, emerging researchers and junior faculty. We remind ourselves often of hooks' (2003) claim that, "if we are not able to find open spaces in closed systems, we doom ourselves by reinforcing the belief that these educational systems cannot be changed" (p. 73). Facilitating an ideological shift within educational institutions is possible, yet only if there is a multilayered approach to address the need for change. It requires dedication from internal agents in educational institutions and organizing from people outside of educational institutions. An important key component to the collective was the inclusion of doctoral student voices. Multiple doctoral student voices can enhance the outcomes of a teaching or research endeavor by illuminating factors that might not be visible to a lone teacher or researcher. Such factors can include but are not limited to narrow perspectives or understanding that occur as the result of teacher/researcher positionality, prior educational experience(s), and/or varying degrees of experience. Additionally, the small size of the group 
provided an intimate space for doctoral students to develop inquiry questions, action plans, support systems, and collaboration among members. Throughout the years, members have supported each other in their trajectories, monitored one another's progress, and held each other accountable. We view these actions as more than academic supports or endeavors; though they reflect our commitments to one another as students, teachers, and scholars, ultimately, it is the interconnectedness of our shared humanity that guides our work.

\section{Relationships of Mutuality}

Martin Luther King, Jr. (1963) used the word mutuality to describe our interconnectedness. He claims that "we are caught in an inescapable network of mutuality, tied in a single garment of destiny. Whatever affects one directly affects all indirectly" (para. 4). Our involvement in the collective helps us argue that our relationships became transformative and empowering. The flattening of the hierarchy present in doctoral students and faculty, and the development of openness and appreciation of the lived experiences of the student teachers and the members of the collective allowed us to see the importance of mutuality.

We suggest that critical pedagogy happens in the intersections of roles and relationships. In our case it was the space where faculty, doctoral students, and student teachers interacted and learned together. The space helped us reconsider how teaching and learning are traditionally thought of and moved us to think of teaching and learning as done with students, not to or for them. Our work started with re-imagining our relationships and roles. It was Dr. Green inviting the doctoral students to collaborate in learning with studentteachers and in teaching the class with her. It was thinking of our research questions together, and the goals for our collaborative inquiry on teaching for social justice. We believe that this is essential in establishing a culture of collaborative critical inquiry and democratizing knowledge production. In developing this shared vision for social justice, we shift in thinking about our individual research agendas to our collaborative research agenda.

This essay is an attempt as doctoral students, teacher educators, youth workers, and social justice minded folks to examine how social justice teaching was sustained and enhanced through a collective critical inquiry group. We do not romanticize our work in urban and rural schools and spaces of teacher education, but instead think of social justice teaching as an ongoing and arduous process. A process which, when supported and sustained through community, holds great potential to disrupt both what it means to be teacher educators and education researchers in training. Ultimately, if we hope to disrupt the practices that have prevailed in teacher training and educational research, we must first disrupt the power relations that exist in colleges of education between faculty and students and faculty and student teachers. 


\section{References}

Adams, M. (2007). Pedagogical frameworks for social justice education. In M. Adams, L. A. Bell, \& P. Griffin (Eds.), Teaching for diversity and social justice (pp. 15-33). Routledge.

Akom, A. A., Cammarota, J., \& Ginwright, S. (2008). Youthtopias: Towards a new paradigm of critical youth studies. Youth Media Reporter, 2(4), 1-30. http://www.youthmediareporter.org/2008/08/youthtopias towards a new para.ht $\underline{\mathrm{ml}}$

Andrews, D. J. C., Richmond, G., \& Stroupe, D. (2017). Teacher education and teaching in the present political landscape: Promoting educational equity through critical inquiry and research. Journal of Teacher Education, 68(2), 121-124. https://doi.org/10.1177/0022487117691243

Aronowitz, S. \& Giroux, H. (1993). Reproduction and resistance in radical theories of schooling in education still under siege: The conservative, liberal and radical debate over schooling. Bergin \& Garvey.

Banks, J. A. (1998). The lives and values of researchers: Implications for educating citizens in a multicultural society. Educational Researcher, 27(7), 4-17. https://doi.org/10.3102/0013189X027007004

Bartolomé, L. I. (2004). Critical pedagogy and teacher education: Radicalizing prospective teachers. Teacher Education Quarterly, 31(1) 97-122. https://www.jstor.org/stable/23478420

Battiste, M. (2004, May 29). Animating sites of postcolonial education: Indigenous knowledge and the humanities. CSSE Plenary Address. http://citeseerx.ist.psu.edu/viewdoc/download?doi=10.1.1.488.6642\&rep=rep1\&typ $\underline{e=p d f}$

Chapman, T. K., \& Hobbel, N. (2010). Introduction: Conversations, problems, and action. In T. K. Chapman \& N. Hobbel (Eds.), Social justice pedagogy across the curriculum (pp. 15). Routledge.

Cochran-Smith, M., \& Lytle, S. (1990). Research on teaching and teacher research: the issues that divide. Educational Research, 19(2), 2-11. https://doi.org/10.3102/0013189X019002002

Cochran-Smith, M., \& Lytle, S. L. (1993). Inside/outside: teacher research and knowledge. Teachers College Press.

Cochran-Smith, M., \& Lytle, S. (1999). Relationship of knowledge and practice: teacher learning in communities. Review of Educational Research in Education, 24, 249-305. https://doi.org/10.3102/0091732X024001249

Cochran-Smith, M., \& Lytle, S. (2009). Inquiry as stance: Practitioner research for the next generation. Teachers College Press.

Cook-Sather, A. (2002). Authorizing students' perspectives: Toward trust, dialogue, and change in education. Educational Researcher, 31(4), 3-14. https://doi.org/10.3102/0013189X031004003 
Darder, A., Baltodano, M. P., \& Torres, R. D. (2009). Critical pedagogy: An introduction. In A. Darder, M. P. Baltodano, \& R. D. Torres (Eds.), The critical pedagogy reader (2nd ed., pp. 1-26). Routledge.

Darling-Hammond, L. (2010). The flat world and education: How America's commitment to equity will determine our future. Teachers College Press.

DeJong, K., \& Love, B. J. (2015). Youth oppression as a technology of colonialism: Conceptual frameworks and possibilities for social justice education praxis. Equity \& Excellence in Education, 48(3), 489-508. https://doi.org/10.1080/10665684.2015.1057086

Duncan-Andrade, J. M. (2004). Toward teacher development for the urban in urban teaching. Teaching Education, 15(4), 339-350.t https://doi.org/10.1080/1047621042000304475

Duncan-Andrade, J. M. R., \& Morrell, E. (2008). The art of critical pedagogy: Possibilities for moving from theory to practice in urban schools (Vol. 285). Peter Lang.

Emdin, C. (2016). For White folks who teach in the hood... and the rest of $y^{\prime}$ all too: Reality pedagogy and urban education. Beacon Press

Freire, P. (2000). Pedagogy of the oppressed. Bloomsbury Academic.

Giroux, H. (1988). Toward a critical pedagogy of learning. Bergin \& Garvey.

hooks, b. (2003). Teaching community: A pedagogy of hope (Vol. 36). Psychology Press.

Jones, S. (2014). Writing and teaching to change the world: Connecting with our most vulnerable students. The National Writing Project.

King Jr., M. L. (1994). Letter from the Birmingham jail. Harper San Francisco.

Ladson-Billings, G. (1995). But that's just good teaching! The case for culturally relevant pedagogy. Theory Into Practice, 34(3), 159-165. http://doi.org/10.1080/00405849509543675

Lipman, P. (2009). Beyond accountability: Toward schools that create new people for a new way of life. In A. Darder, M. P. Baltodano \& R. D. Torres (Eds.), Critical pedagogy reader (2nd ed.). (pp. 364-383). Routledge.

Matias, C. E. (2013a). Tears worth telling: Urban teaching and the possibilities of racial justice. Multicultural Perspectives, 15(4), 187-193. https://doi.org/10.1080/15210960.2013.844603

Matias, C. E. (2013b). Check yo'self before you wreck yo'self and our kids: Counterstories from culturally responsive white teachers?... to culturally responsive white teachers! Interdisciplinary Journal of Teaching and Learning, 3(2), 68-81. https://eric.ed.gov/?id=EJ1063061

Matias, C. E., \& Mackey, J. (2016). Breakin' down whiteness in antiracist teaching: Introducing critical whiteness pedagogy. Urban Review, 48(1), 32-50. https://doi.org/10.1007/s11256-015-0344-7

McNeil, L. (2009). Standardization, defensive teaching, and the problems of control. The Critical Pedagogy Reader, 2, 384-396.

Mirra, N. \& Garcia, A. (2017). Civic participation reimagined: Youth interrogation and innovation in the multimodal public sphere. Review of Research in Education, 41(1), 136-158. http://doi.org/10.3102/0091732X17690121 
Mitra, D. L. (2003). Student voice in school reform: Reframing student-teacher relationships. McGill Journal of Education, 38(2), 289-304. https://mje.mcgill.ca/article/view/8686

Nieto, S., Gordon, S., \& Yearwood, J. (2002). Teachers' experiences in a critical inquiry group: A conversation in three voices. Teaching Education, 13(3), 341-355. http://dx.doi.org/10.1080/1047621022000023316

Nieto, S. (2003). What keeps teachers going? Teachers College Press.

Paris, D. (2012). Culturally sustaining pedagogy: A needed change in stance, terminology, and practice. Educational Researcher, 41(3), 93-97. http://dx.doi.org/10.3102/0013189x12441244

Paris, D., \& Alim, H. S. (Eds.). (2017). Culturally sustaining pedagogies: Teaching and learning for justice in a changing world. Teachers College Press.

Patel, L. (2016). Decolonizing educational research: From ownership to answerability. Routledge.

Picower, B. (2007). Supporting new educators to teach for social justice: The critical inquiry project model. Penn GSE Perspectives on Urban Education, 5(1), 1-16. https://eric.ed.gov/?id=EJ852632

Picower, B. (2012). Practice what you teach: Social justice education in the classroom and the streets (Vol. 13). Routledge.

San Pedro, T., \& Kinloch, V. (2017). Toward projects in humanization: Research on cocreating and sustaining dialogic relationships. American Educational Research Journal, 54(1_suppl), 373S-394S. https://doi.org/10.3102/0002831216671210

Sleeter, C. E. (2012). Confronting the marginalization of culturally responsive pedagogy. Urban Education, 47(3), 562-584. http://doi.org/10.1177/0042085911431472

Smith, L. T. (2012). Decolonizing methodologies: Research and indigenous peoples (2nd ed.). Zed Books.

Solórzano, D. G., \& Yosso, T. J. (2002). Critical race methodology: Counter-storytelling as an analytical framework for education research. Qualitative Inquiry, 8(1), 23-44. https://doi.org/10.1177/107780040200800103

Stauber, L. (2017). Turning in or tuning out? Listening to silences in education for critical political consciousness. International Journal of Qualitative Studies in Education, 30(6), 560-575. https://doi.org/10.1080/09518398.2016.1269971

Tuck, E. (2009). Suspending damage: A letter to communities. Harvard Educational Review, 79(3), 409-427. https://doi.org/10.17763/haer.79.3.n0016675661t3n15

Tuck, E., \& Yang, K. W. (2014). R-Words: Refusing research. In D. Paris \& M. T. Winn (Eds.), Humanizing research: Decolonizing qualitative inquiry with youth and communities (pp. 223-247). Sage. 